\title{
PENERAPAN BIOFILIK ARSITEKTUR DAN GEOMETRI FRAKTAL PADA DESAIN FASILITAS KONSERVASI PEMBUDIDAYAAN TERUMBU KARANG DI LABUAN BAJO
}

\author{
Nadya Amelia ${ }^{1)}$, Priscilla Epifania Ariaji ${ }^{2)}$ \\ 1)Program Studi S1 Arsitektur, Fakultas Teknik, Universitas Tarumanagara, nadya.amelia23@gmail.com \\ 2) Program Studi S1 Arsitektur, Fakultas Teknik, Universitas Tarumanagara, priscillae@ft.untar.ac.id
}

Masuk: 04-07-2021, revisi: 15-08-2021, diterima untuk diterbitkan: 23-10-2021

\begin{abstract}
Abstrak
Fasilitas Konservasi Pembudidayaan Terumbu Karang adalah bangunan yang berada di wilayah Pantai Merah, Labuan Bajo, Nusa Tenggara Timur. Metode Biofilik Arsitektur dan Geometri Fraktal adalah metode desain yang digunakan sebagai acuan dalam bangunan ini. Prinsip-prinsip dan pattern yang digunakan memberikan pengalaman dan pandangan untuk meningkatkan pembudidayaan terumbu karang serta menjaga keberlangsung hidup terumbu karang berbasis rekreasi pembelajaran dan budidaya. Prinsip Nature In Space, Natural Analogoues dan Natural of The Space diterapkan dalam bangunan yang ditunjukkan dengan adanya bentuk bangunan floating, berdekatan dengan habitat alam di laut dan fungsi bangunan yang mengutamakan ekosistem terumbu karang. Penerapan Geometri Fraktal dapat dilihat dengan adanya penerapan fasad bangunan yang terinspirasi dari bentuk transformasi massa berlapis lapis mengikuti lapisan terumbu karang dan struktur pattern terumbu karang dan teknologi serta sistem bangunan yang ramah lingkungan. Keseluruhan desain bangunan menciptakan unsur pemeliharaan ekologi terhadap ekosistem laut dengan memperhatikan keberlangsungan hidup terumbu karang.
\end{abstract}

Kata kunci: biofilik arsitektur; ekosistem laut; fasilitas konservasi; geometri fraktal

\begin{abstract}
The Coral Reef Cultivation Conservation Facility is a project located in the Red Beach area, Labuan Bajo, East Nusa Tenggara. Architectural Biophilic Methods and Fractal Geometry are design methods used as references in this building. The principles and patterns used provide experiences and perspectives to improve coral reef cultivation and maintain the survival of coral reefs based on learning and aquaculture recreation. The principles of Nature In Space, Natural Analogoues and Natural Of The Space are applied in the project which is indicated by the existence of floating building forms, adjacent to natural habitats in the sea and building functions that prioritize coral reef ecosystems. The application of Fractal Geometry can be seen from the application of building facades that are inspired by the form of mass transformation in layers following the layers of coral reefs and coral reef pattern structures and environmentally friendly building technology and systems. The overall project design creates an element of ecological maintenance for marine ecosystems by taking into account the survival of coral reefs.
\end{abstract}

Keywords: biophilic architectural; conservation facility; fractal geometry; marine ecosystem

\section{PENDAHULUAN}

\section{Latar Belakang}

Keadaan ekologi di Indonesia terbilang cukup memprihatinkan akibat adanya kerusakan lingkungan terhadap ekosistem laut. Ekosistem laut di Indonesia dikelompokkan dari berbagai jenis aspek seperti hutan bakau, rumput laut dan terumbu karang. Status kondisi terumbu karang di Indonesia terdiri dari berbagai kategori seperti sangat baik, baik, cukup baik dan rusak. Kategori terumbu karang rusak dan cukup baik mendominasi wilayah perairan ekosistem laut Indonesia. Hal ini ditunjukkan dengan adanya peningkatan status presentase 
kategori rusak terumbu karang sebesar 1,03\% pertahunnya (LIPI. 2017). Buruknya status terumbu karang di Indonesia diakibatkan oleh banyaknya sampah dan tindakan penangkapan yang merusak.

Wilayah kawasan Labuan bajo merupakan wilayah yang memiliki ekosistem laut cukup banyak khususnya titik lokasi persebaran terumbu karang (LIPI. 2017). Kawasan Labuan Bajo sendiri adalah kawasan yang saat ini marak dikunjungi oleh wisatawan untuk berekreasi. Kawasan ini dikenal dengan adanya keindahaan kekayaan ekosistem lautnya. Dengan kondisi saat ini yang banyaknya wisatawan berkunjung menyebabkan kondisi status terumbu karang di kawasan ini cukup memprihatinkan dan perlu adanya pemeliharaan terhadap keberlangsungan hidup ekosistem laut. Kurangnya tempat untuk memfasilitasi pembudidayaan terumbu karang merupakan salah satu aspek mengapa Labuan Bajo dipilih. Fasilitas konservasi pembudidayaan terumbu karang dapat menjadi jawaban untuk membantu memfasilitasi dalam melestarikan serta mempertahankan keberlangsung hidup terumbu karang. Namun pembangunan fasilitas konservasi juga memerlukan berbagai aspek terhadap kepentingan ekologi ekosistem laut tanpa harus merusaknya. Maka dari itu, untuk menghindari perusakan ekosistem laut, diperlukan pendekatan desain berbasis biofilik arsitektur dan geometri fraktal untuk memberikan keseimbangan antara ekosistem laut dan tujuan dari bangunan.

Metode pendekatan berbasis biofilik arsitektur dan geometri fraktal dapat membantu fasilitas konservasi dalam mencapai tujuan dari program program yang dijalankan. Pendekatan yang dimiliki metode biofilik serta geometri fraktal dapat memberikan unsur rasa ingin melestarikan alam sebagai acuan atau dasar masyarakat menjaga keberlangungan ekosistem terumbu karang di Indonesia. Dengan adanya penerapan metode pada rancangan desain fasilitas konservasi diharapkan dapat membantu menciptakan tujuan fungsi bangunan dalam meningkatkan keberlangsungan ekosistem terumbu karang.

\section{Rumusan Permasalahan}

Buruknya status kondisi terumbu karang di Indonesia yang membuat keberlangsungan hidup ekosistem laut terancam. Wilayah kawasan Labuan Bajo merupakan titik lokasi persebaran yang cukup banyak terhadap populasi terumbu karang. Banyaknya sampah dan penangkapan yang merusak membuat kehidupan terumbu karang terancam. Selain itu, Labuan Bajo juga merupakan wilayah destinasi wisata yang sedang marak saat ini akibat wisata laut yang dimiliki. Tulisan ini berfokus pada bagaimana memberikan wadah untuk memfasilitasi program pembudidayaan terumbu karang tanpa merusak ekosistem laut dengan menggunakan pendekatan desain berbasis biofilik arsitektur dan geometri fraktal dalam menjaga kelestarian terhadap keberlangsungan ekosistem terumbu karang dengan prinsip-prinsip yang diterapkan. Penggunaan prinsip-prinsip pada metode biofilik arsitektur dan geometri fraktal membantu dalam mencapai pemeliharaan ekosistem dari segi pengalaman, rancangan, struktur dan fungsi dalam bangunan.

\section{Tujuan}

Tulisan ini bertujuan untuk mengaplikasikan metode biofilik arsitektur dan geometri fraktal pada bangunan fasilitas konservasi pembudidayaan terumbu karang tanpa menghilangkan unsur pelestarian ekosistem laut. Penerapan-penerapan metode biofilik arsitektur dan geometri fraktal yang ditunjukkan dari segi struktur dan rancangan bangunan berguna untuk memberikan rasa dan pengalaman dari segala unsur desain bangunan. Selain itu, tujuan dari bangunan ini dibuat untuk membantu mewadahi rumah untuk keberlanjutan ekosistem terumbu karang serta memfasilitasi pembudidayaan terumbu karang tanpa merusak lingkungan yang disesuaikan dengan prinsip-prinsip biofilik arsitektur. 


\section{KAJIAN LITERATUR}

\section{Beyond Ecology}

Menurut Sutanto (2020), Beyond Ecology atau disebut melampaui ekologi merupakan konsep yang berfungsi untuk melestarikan alam serta lingkungan untuk memberikan kehidupan dalam meningkatkan efisiensi energi dan sumber daya alam. Hal ini menunjukkan bahwa kondisi ekosistem mengalami kondisi kecepatan dan percepatan yang menjadikan sebagai titik jantung dunia dan ekosistem sekitar. Dalam konsep melampaui ekologi terdapat berbagai parameter yang diperhitungkan sebagai berikut:

- Energi and Emision: Kemampuan penerapan $\mathrm{CO} 2$ emissions untuk pengoperasional bangunan dan minimalisir efek karbon

- Adaptation: Kemampuan melakukan riset dan desain dengan berbagai dampak

- Resilience: Kemampuan membangun untuk kelanjutan 'kelanjutan' hunian dan pemulihan

- Sustainable Digital: Kemampuan untuk melihat data mengenai lingkungan dalam taktik dan strategi desain

- New Technology: Kemampuan memanfaatkan teknologi terbaru agar meningkatkan kualitas pada program bangunan

\section{Ekosistem Terumbu Karang}

Terumbu karang merupakan suatu ekosistem khas di wilayah pesisir daerah tropis. Ekosistem terumbu karang dipengaruhi oleh berbagai faktor lingkungan seperti tingkat kejernihan air, arus, salinitas dan suhu. Tingkat kejernihan air dipengaruhi partikel tersuspensi akibat pelumpuran yang berpengaruh terhadap jumlah cahaya yang masuk ke dalam laut. Terumbu karang terbentuk dari ari endapan-endapan massif kalsium karbonat (CaCO3), yang dihasilkan oleh organisme karang pembentuk terumbu (karang hermatipik) dari filum Cnidaria yang bersimbiosis dengan zooxantellae (Hutagalung, 2019).

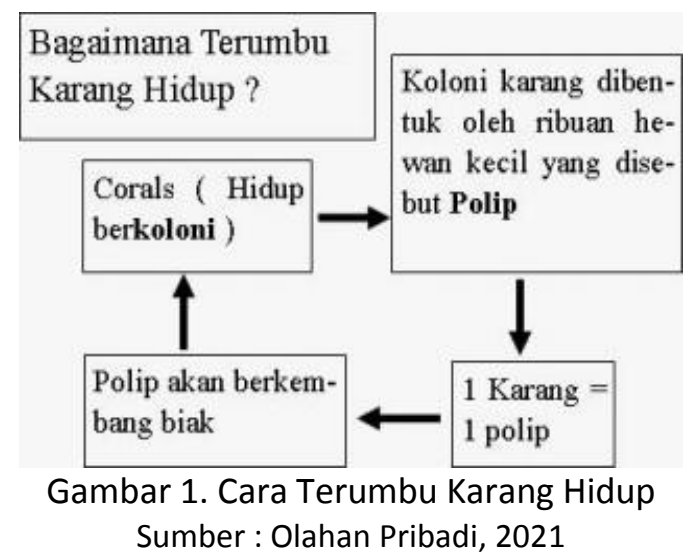

Setiap karang merupakan 1 polip. Polip akan berkembang biak dan hidup berkoloni sehingga menjadi kumpulan berbagai polip atau disebut karang (corals). Karang-karang tersebut akan membentuk ribuan hewan kecil. (Hutagalung, 2019).

\section{Dampak Kegiatan Manusia pada Ekosistem Terumbu Karang}

Hubungan aksi timbal balik merupakan hal yang cukup diperlukan dalam menjalankan ekosistem terumbu karang. Segala kegiatan memberikan dampak yang berpotensial. Namun faktanya, masih banyak yang melakukan tindakan yang merugikan ekosistem terumbu karang yang menyebabkan hubungan timbal balik tidak berjalan dengan baik. Beberapa kegiatan manusia yang memberikan dampak potensial terhadap ekosistem terumbu karang (Restu, 2016). 
Tabel 1. Dampak Kegiatan Potensial Ekosistem Terumbu Karang

\begin{tabular}{cc}
\hline Kegiatan & Dampak Potensial \\
\hline $\begin{array}{c}\text { Penambangan karang dengan } \\
\text { bahan peledak }\end{array}$ & $\begin{array}{c}\text { Perusakan habitat dan kematian massal } \\
\text { hewan karang }\end{array}$ \\
\hline Pembuangan limbah & $\begin{array}{c}\text { Meningkatnya suhu air yang dapat mematikan } \\
\text { karang dan biota lau }\end{array}$ \\
\hline Kepariwisataan & $-\quad$ Pencemaran limbah \\
& $-\quad \begin{array}{c}\text { Kerusakan fisik karang oleh jangkar kapal } \\
\text { Peningkatan suhu air karena buangan } \\
\text { air pendingin }\end{array}$ \\
\hline $\begin{array}{c}\text { Pengerukan di sekitar terumbu } \\
\text { karang }\end{array}$ & $\begin{array}{c}\text { Meningkatnya kekeruhan yang menggangu } \\
\text { pertumbuhan karang }\end{array}$ \\
\hline
\end{tabular}

Sumber : Restu, 2016

\section{Pembudidayaan Terumbu Karang}

Metode pembudidayaan terumbu karang yang sesuai dapat membantu dan melestarikan keberlangsungan hidup terumbu karang. Metode tersebut dapat berupa cara seperti planting corals. Dengan cara menanam bibit karang ke batu dan akan dilepas ke laut setelah memiliki pondasi yang cukup kuat merupakan salah satu metode yang dapat dikembangkan dan dijadikan solusi untuk memelihara keseimbangan ekosistem terumbu karang. Planting Corals merupakan tindakan yang memiliki hubungan mutualisme antara manusia dengan terumbu karang serta memberikan dampak positif bagi lingkungan sekitar. Dalam menjalankan planting corals menyelamatkan karang atau koloni yang tercemar dalam keadaan hidup. Proses tersebut disebut fraging coral. (Hutagalung, 2019).

Setelah proses tersebut dijalankan, proses tersebut menghasilkan polip. Setelah menghasilkan polip, polip tersebut akan di tanam di sebuah media berupa batu polip yang ditanam akan menjadi bayi karang (baby corals). Dalam kehidupannya baby corals yang baru ditanam tidak dapat langsung dikembalikan ke habitat aslinya yaitu laut karena masih belum cukup kuat untuk dapat bertahan dari arus serta gelombang yang ada di laut. Hal ini masih memerlukan adanya penangkaran dalam menjaga keberlangsung kehidupan baby corals. Terumbu karang memiliki kecepatan pertumbuhan sekitar $5-10 \mathrm{~cm}$ per tahun. Terumbu karang yang ada saat ini mencapai 10-20 ribu tahun. (Hutagalung, 2019).

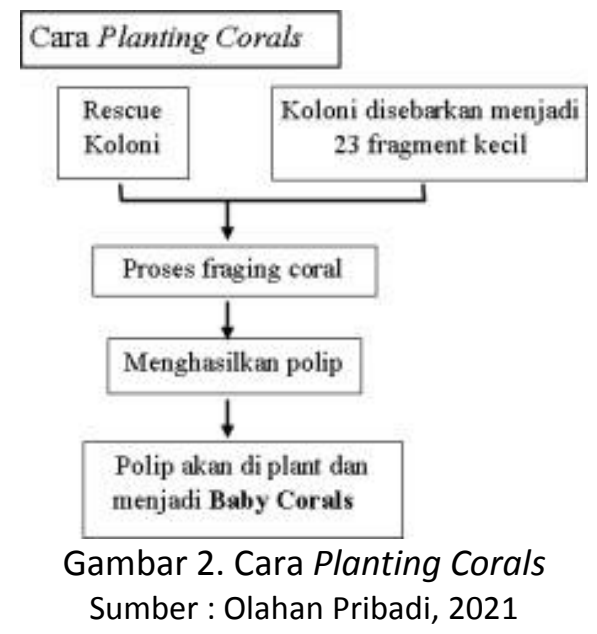

\section{Teori Biofilik Arsitektur}

Biofilik Arsitektur merupakan metode pendekatan rancangan desain pada arsitektur yang bertujuan untuk melakukan berbagai pendekatan dalam membawa unsur makhluk hidup 
khususnya manusia untuk lebih dekat dengan alam secara fisik maupun psikologi. Desain biofilik terdapat 14 pattern yang memiliki berbagai prinsip dalam penerapannya. Dimana terdapat 3 parameter dari ke 14 pattern tersebut mulai dari Nature in The Space sebagai prinsip yang memberikan akses maupun unsur alam terhadap bentuk maupun penempatan pada desain bangunan, Natural Analogues sebagai penerapan prinsip terhadap pola, bentuk serta penggunaan material alam dan Nature of the space sebagai desain dengan memberikan unsur sensasi serta perasaan dekat dengan alam. (Terrapin, 2014).

\section{Pattern Prinsip Biofilik Arsitektur}

a. Nature in The Space

- Hubungan secara Visual (Visual connection with nature): Memberi Akses manusia dengan pemandangan alam, sistem kehidupan serta proses alami

- Hubungan Non Visual (Non-visual connection with nature) : Koneksi dengan alam melalui indra pendengaran, penciuman, peraba dan perasa

- Stimulus sensor tidak beritme (Non-rhytmic sensory stimuli): Sensorik alami yang menarik perhatian

- Variasi perubahan panas \& udara (Thermal and airflow variability): Variasi dalam pemberian suhu, kelembapan

- Kehadiran air (Presence of water): Penggunaan unsur air

- Cahaya dinamis dan menyebar (Dynamic and diffuse lighting): Pemanfaatan intensitas cahaya alami

- Hubungan dengan sistem alami (Connection with natural system): Penggunaan material dan elemen dalam mempertahankan bentuk alami

b. Natural Analogues

- Bentuk dan pola biomorfik (Biomorphic forms and patterns): Meniru alam melalui pola dan bentuk

- Hubungan bahan dengan alam (Material Connection with Nature): Penggunaan material dan elemen ekologi

- Kompleksitas dan keteraturan (Complexity and order): Informasi sensorik beragam

c. Nature of the space

- Prospek (Prospect): Mendesain ruang dengan luas

- Tempat perlindungan (Refuge): Memberikan rasa aman

- Misteri (Mystery): Menciptakan rasa menarik

- Resiko \& Bahaya (Risk \& Peril): Pemberian karakteristik ancaman

\section{Geometri Fraktal}

Metode geometri fraktal adalah salah satu ilmu dalam matematika yang mempelajari sifat-sifat dan perilaku fraktal. Dalam rancangan desain arsitektur geometri fraktal merupakan kajian dalam ilmu matematik yang membahas tentang bentuk dari fraktal atau bentuk apa saja yang bersifat self-similarity. Penerapan ini dapat mengungkapkan konsep-konsep baru dalam metode perancangan bangunan arsitektur. (Johansen Mandey, J. W, 2016)

\section{METODE}

\section{Metode Perancangan Biofilik Arsitektur}

Dalam upaya menciptakan pelestarian dan pembudidayaan keberlangsungan hidup ekosistem terumbu karang dengan membawa pendekatan untuk membawa makhluk hidup lebih dekat dengan alam secara fisik maupun psikologi maka dalam perancangan menggunakan metode biofilik. Biofilik merupakan pendekatan yang digunakan dalam bangunan meningkatkan konektivitas ke lingkungan alam dengan kondisi ruang, tempat serta sifat langsung maupun tidak langsung. 
Dalam desain biofilik terdapat 14 pattern (Terrapin, 2014) yang memiliki prinsip dalam penerapannya, keseluruhan prinsip tersebut dikelompokkan dalam tiga kelompok utama (Fadhila Naifah Irbah, 2020). Biofilik didasari dari 3 prinsip, pertama adalah kehadiran seperti keberadaan alam baik terlihat maupun tidak terlihat. Kedua merupakan sifat sifat variabilitas seperti hembusan angin maupun cahaya. Ketiga adalah bentuk, menghadirkan pola-pola alam dalam bangunan. Penggunaan metode biofilik arsitektur berfokus untuk acuan dalam perancangan desain dalam memberikan unsur kepedulian ekosistem laut yang menjaga keberlangsung hidup terumbu karang di Indonesia.

\section{Penerapan Tipe-Tipe Metode Biofilik}

1. Nature in The Space

- Visual Connection with Nature: Penempatan program bangunan yang berada di alam atau dekat alam dan berada di habitat asli terumbu karang

- Non-Visual connection with nature: Memberikan koneksi dengan alam melalui indra pendengaran serta penciuman

- Presence of Water: Pemberian unsur air untuk mendapatkan kondisi individu dalam melihat, mendengar dan menyentuh elemen

2. Natural Analogues

- Material Connection with Nature: Penggunaan material dan elemen alam untuk mencerminkan ekologi

3. Nature of The Space

- Mystery : Menciptakan rasa menarik dan pengalaman lebih dalam

Dengan adanya pendekatan menggunakan biofilik arsitektur dapat membantu mencapai beyond ecology pada desain fasilitas konservasi dengan prinsip unsur teknologi yang terbarukan serta menjaga keberlangsungan ekosistem yang diterapkan pada fasilitas konservasi (Terrapin, 2014).

\section{Metode Perancangan Geometri fraktal}

Dalam arsitektur, geometri fraktal merupakan konsep yang berkembang dari penggunaan geometri sebagai bentuk fasad arsitektur dan bentuk, baik secara dua dimensi maupun tiga dimensi. Penggunaan geometri fraktal dianggap lebih mendekati bentuk dan proses transformasi bentuk yang terjadi di alam. Metode ini dimulai dengan pemakaian garis panjang tanpa lebar. (Johansen Mandey, J. W, 2016)

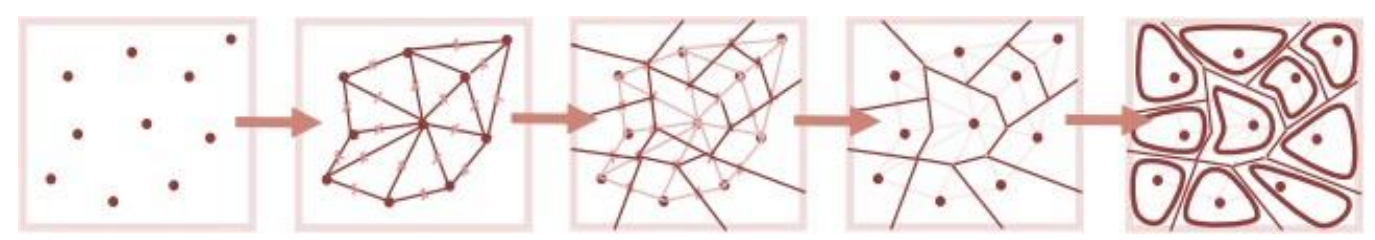

Gambar 3. Rancangan Pola Geometri Fraktal

Sumber: Olahan Pribadi Berdasarkan Teori Geometri Fraktal , 2021

Geometri fraktal bermulai dari pola titik-titik yang menyerupai bentuk karang yang terlihat dari atas. Titik-titik tersebut membentuk pola seperti cabang cabang karang. Pola pola tersebut didasari oleh bentuk karang jenis acropora khususnya famili acropora digitifera dan acropora divaricata. Dalam pembentukan pola tersebut, pengaplikasian dalam bangunan terlihat dalam bentuk kaca serta fasad pada bangunan. Pola tersebut diaplikasikan pada setiap massa yang ada dalam bangunan. (Johansen Mandey, J. W, 2016) 


\section{DISKUSI DAN HASIL}

\section{Lokasi Tapak dan Program Bangunan}

Lokasi tapak berada di Pantai Pink atau biasa dikenal dengan Pantai Merah Labuan Bajo berada di Pulau Komodo, Flores Barat, Nusa Tenggara Timur

Luas Tapak : :15.000m2

Fungsi Lahan : Zona Pemanfaatan, Pengembangan dan Pelestarian Wisata Bahari

Radius

\section{: $50 \mathrm{~m}$ dari daratan dan $150 \mathrm{~m}$ dari Pantai Merah}

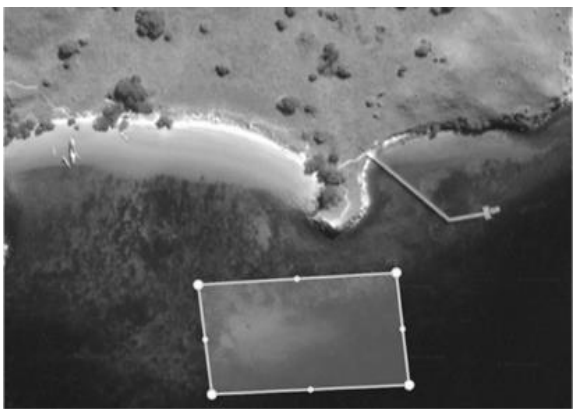

Gambar 4. Lokasi Tapak

Sumber: Olahan Pribadi, 2021

Berdasarkan hasil dari pengumpulan data, diusulkan program utama yaitu fasilitas konservasi hal ini sebagai wadah dalam menjaga segala tindakan dalam menjaga keberlangsungan hidup terumbu karang yang berfokus pada pengembalian kesadaran masyarakat akan pentingnya menjaga ekosistem terumbu karang melalui edukasi serta reaksi. Program bangunan konservasi mengacu pada keberlangsungan hidup ekosistem terumbu karang yang didasari oleh prinsip-prinsip dari pattern biofilik arsitektur. Penerapan prinsip visual connection nature dalam biofilik arsitektur ditunjukkan dalam desain bangunan floating untuk mempermudah jangkauan program terhadap pengembalian terumbu karang ke laut (habitat asli) dengan metode selam. Segala kegiatan tersebut bertujuan untuk melestarikan terumbu karang dengan cara penanaman karang secara banyak, memfasilitasi dalam menyiapkan rumah terumbu karang dan membantu mendukung perkembangbiakan terumbu karang dengan mengacu prinsip biofilik arsitektur non visual connection nature dari segi reaksi.

\section{Skema Desain}

Konsep gubahan massa dimulai dari tapak yang dibagi menjadi beberapa zona sesuai dengan program yang diambil seperti program akuarium, konservasi serta penghubung (coral garden). Setelah dibagi menjadi berbagai zona, bentuk massa akan disesuaikan dan mengadaptasi dari bentuk tapak. Setelah itu, proses penambahan kanopi dengan bentuk lengkung pada massa konservasi akan menyesuaikan bentuk atap yang berbentuk lingkaran untuk membedakan lantai. Selain atap, pengaplikasian material pada bangunan seperti kaca yang mengadaptasi salah satu prinsip desain metode biofilik arsitektur (Hubungan Bahan dengan Alam) yang ramah lingkungan yang ditutupi dengan penutup kaca menggunakan rangka secondary skin dengan bentuk fraktal Corals yang terinspirasi dari struktur terumbu karang.

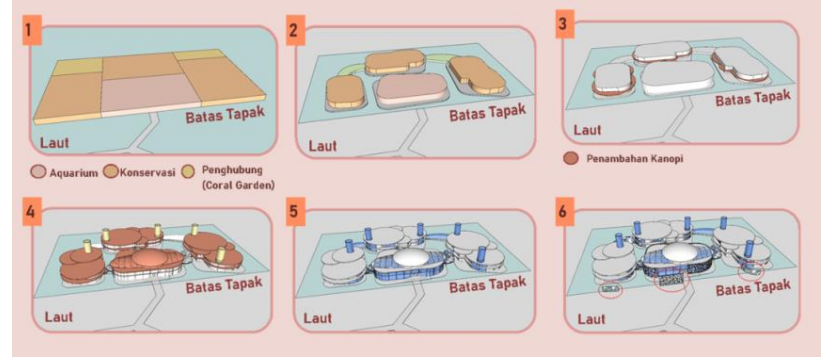

Gambar 5. Konsep Gubahan Massa

Sumber : Olahan Pribadi, 2021 
Seperti halnya habitat karang yang berbentuk berlapis lapis, bangunan ini juga mengaplikasikan metode bentuk geometri fraktal yang mempunyai bentuk dasar lingkaran dan disusun tidak beraturan. Transformasi berlapis lapis ini menyerupai bentuk karang yang dijadikan sebagai acuan dalam bentuk massa.
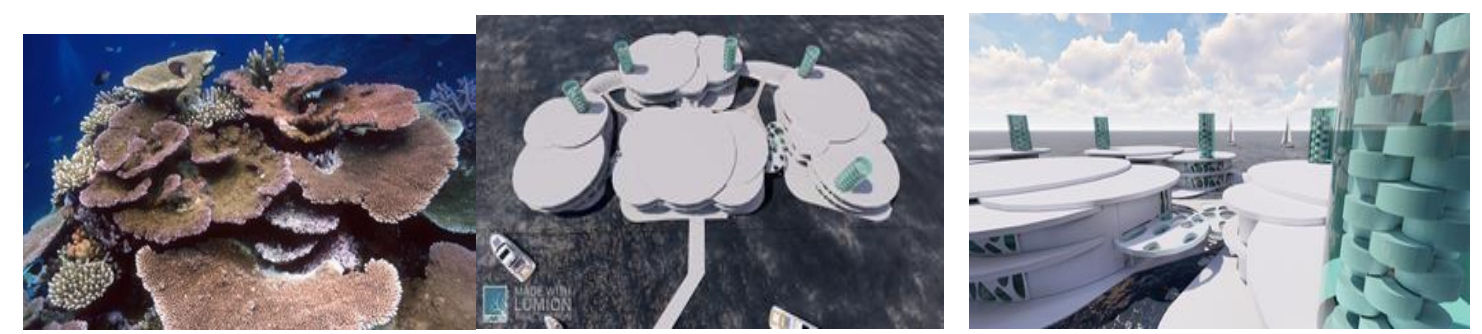

Gambar 6. Transformasi Massa

Sumber : Olahan Pribadi, 2021

Selain itu, Bangunan ini menerapkan proses pembentukan massa yang terinspirasi dari terumbu karang. Konsep gubahan massa dimulai dari tapak yang dibagi menjadi beberapa zona sesuai dengan program yang diambil seperti program akuarium, konservasi serta penghubung (coral garden)

\section{Penerapan Metode Biofilik Arsitektur dan Geometri fraktal pada Bangunan}

Prinsip utama yang diterapkan dalam bangunan sesuai dengan biofilik arsitektur ada prinsip visual connection with nature yang memberikan penempatan program bangunan berada di alam dan berdekatan langsung dengan habitat asli. Bangunan konservasi pembudidayaan terumbu karang ini mempunyai struktur bangunan yang floating guna menjangkau titik-titik lokasi monitoring pembudidayaan terumbu karang.
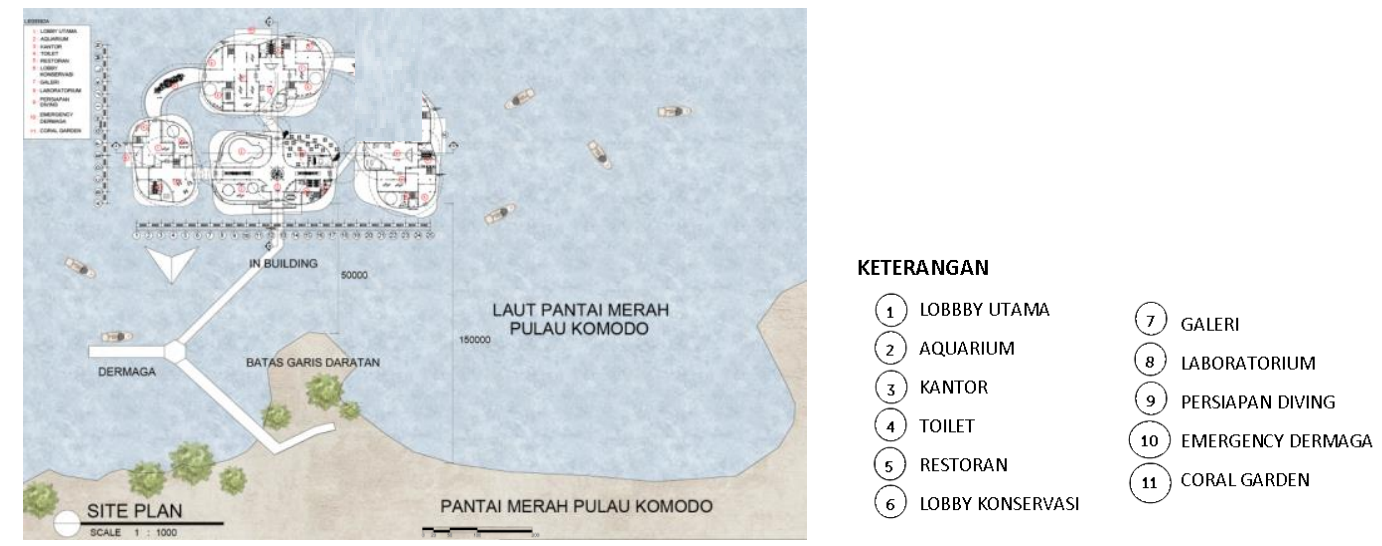

Gambar 7. Site Plan Bangunan Apung

Sumber : Olahan Pribadi, 2021

Selain itu, penerapan geometri fraktal pada bangunan ditunjukkan pada fasad yang mengelilingi seluruh bangunan. Bentuk geometri fraktal yang terinspirasi dari patternpattern struktur terumbu karang yang berguna untuk menimbulkan rasa dekat dengan ekosistem terumbu karang serta bertujuan untuk dijadikan secondary skin dalam meredam panas pada bangunan. 


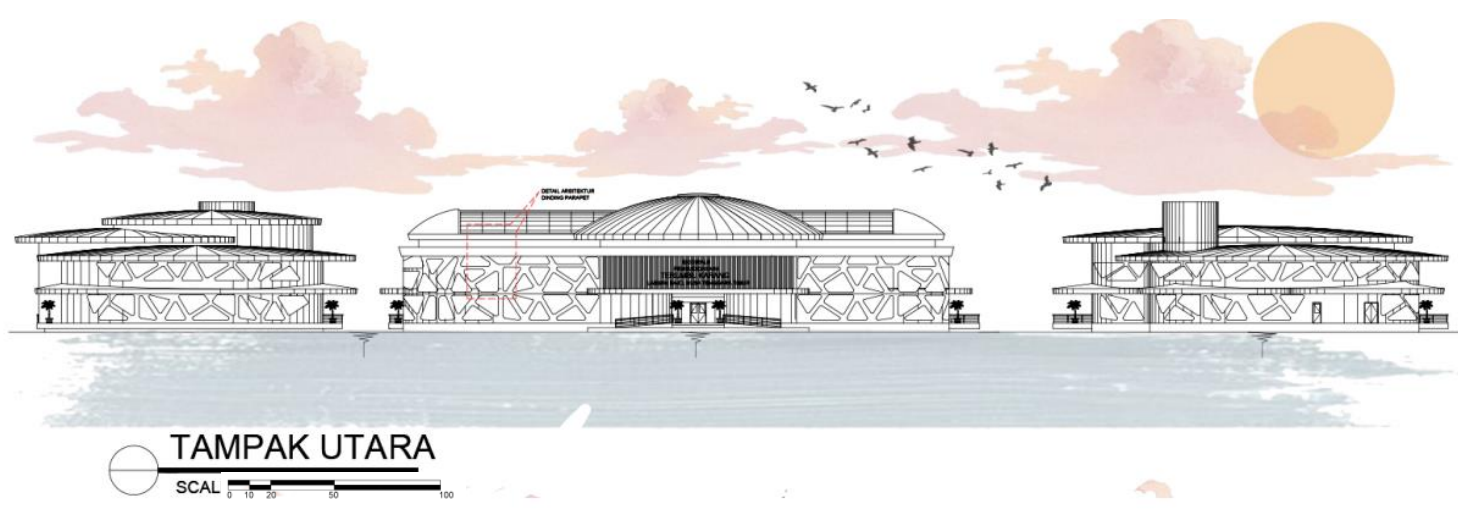

Gambar 8. Penerapan Geometri Fraktal pada Parapet Dinding Sumber : Olahan Pribadi, 2021

Dalam perancangan desain fasilitas konservasi, penerapan pola prinsip biofilik arsitektur ditunjukkan sebagai berikut :

1. Hubungan secara Visual (Visual Connection with Nature): Penempatan program bangunan yang berada di alam yang berdekatan langsung dengan habitat asli terumbu karang untuk memberikan pemandangan alam dalam meningkatkan rasa kepedulian manusia dengan melestarikan dan menjaga terumbu karang. Dalam denah juga terlihat bahwa setiap massa saling terkoneksi satu dengan yang lainnya.
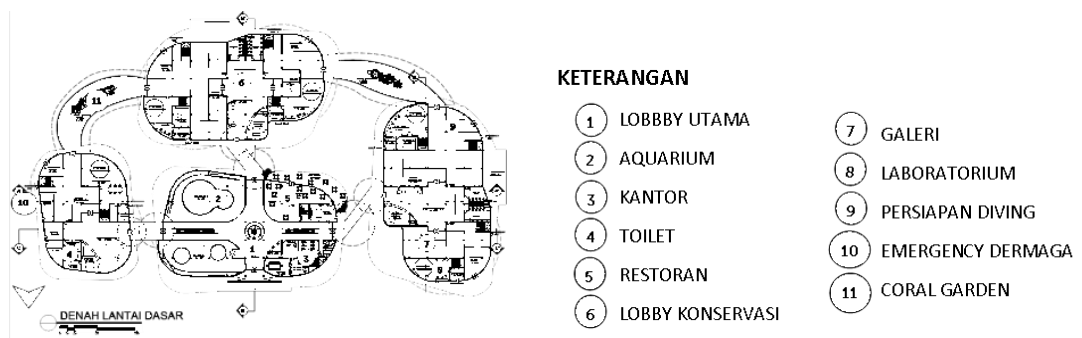

Gambar 9. Penerapan Visual Connection pada Bangunan Sumber : Olahan Pribadi, 2021

2. Hubungan Non Visual (Non-visual connection with nature): Penempatan bangunan pelestarian terumbu karang di laut (floating) akan memberikan penciuman serta pendengaran kepada manusia dan secara tidak langsung memberikan hubungan dan suasana kedekatan antara manusia dan alam.

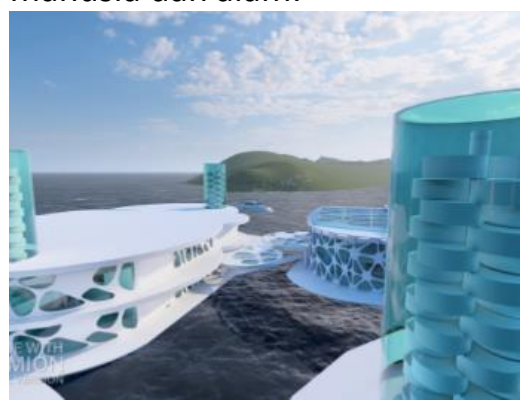

Gambar 10. Penerapan Floating Building Sumber : Olahan Pribadi, 2021

3. Kehadiran Air (Presence of water): Penerapan bangunan dengan floating dan underwater serta penempatan yang disekeliling air berguna untuk memberikan kesadaran akan kondisi alam sekitar yang harus dijaga. 


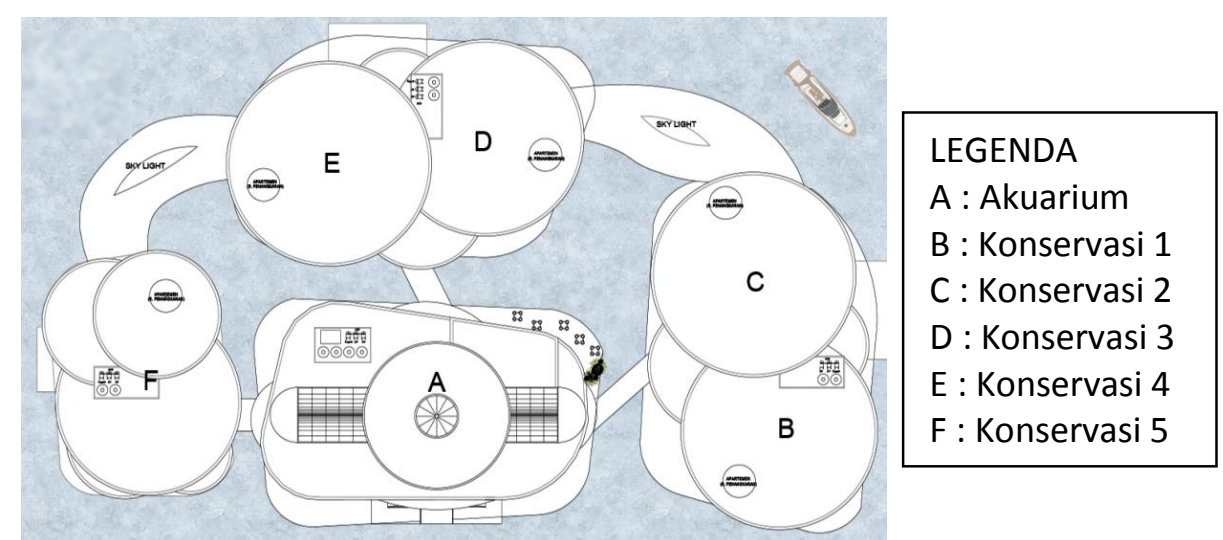

Gambar 11. Blok Plan Penerapan Kehadiran Air pada Bangunan Sumber : Olahan Pribadi, 2021

4. Hubungan bahan dengan alam (Material Connection with Nature): Menggunakan material yang ecofriendly seperti kaca.

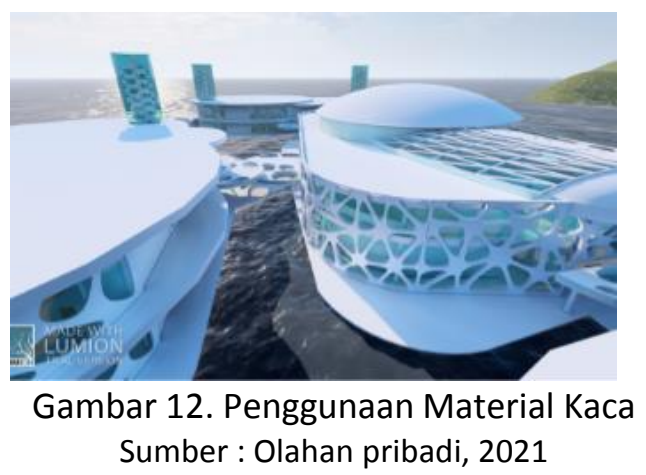

5. Misteri (Mystery): Pengalaman "dekat dengan alam" dengan menghasilkan kegiatan yang berdampak positif bagi alam (menjaga dan melestarikan terumbu karang dengan planting corals). Selain itu, penerapan metode geometri fraktal ditunjukkan dengan adanya pembentukan fasad pada bangunan dengan menggunakan material kaca yang dibentuk dengan rangka rangka yang menyerupai pola bentuk jenis terumbu karang.

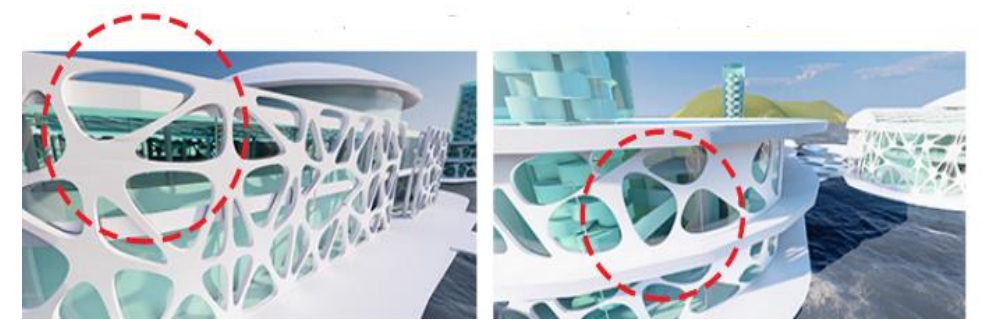

Gambar 13. Penggunaan Pola Geometri fraktal pada Fasad Bangunan Sumber : Olahan Pribadi, 2021

\section{Konsep Biofilik Arsitektur dan Geometri fraktal pada Struktur Bangunan}

Pada prinsip biofilik arsitektur hubungan non visual (Non-visual connection with nature) bangunan dibuat untuk ditempatkan mendekati habitat asli terumbu karang sehingga bangunan ditempatkan secara floating. Dalam bangunan floating diperlukan struktur bangunan yang dapat menjaga keberlangsungan ekosistem terumbu karang di laut.

Sesuai dengan konsep biofilik yang menjaga keberlangsungan alam, fasilitas konservasi 
menerapkan material bangunan apung menggunakan B-Foam. B-Foam digunakan sebagai material dalam pembentukan struktur apung pada bangunan yang dapat mengakomodasi terhadap seluruh kegiatan dalam bangunan, penggunaan material yang tahan air laut, sistem material prefabrikasi, aman serta memiliki kualitas dan harga yang terjangkau.

Detail pada pondasi bangunan dibuat terapung dengan menggunakan pondasi B-Foam. Struktur pondasi $B$-foam terdiri dari berbagai kotak komposite yang dihubungkan dengan berbagai sambungan kotak komposite lainnya. Sehingga proses pembentukan B-foam dilakukan secara prefabrikasi.

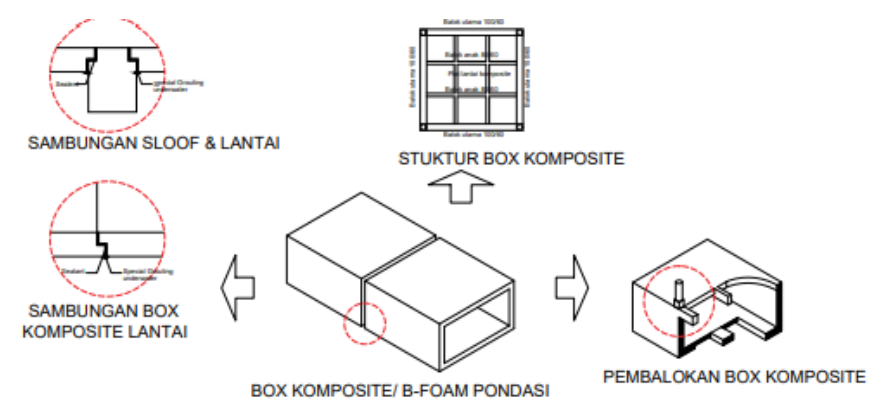

Gambar 14. Detail Struktur Pondasi B-Foam

Sumber : Olahan Pribadi, 2021

Selain itu, dalam struktur bangunan metode geometri fraktal juga diterapkan dalam pembentukan fasad dinding pada bangunan. Detail parapet dinding yang dijadikan sebagai penerapan geometri fraktal ditunjukkan dengan penggunaan material rangka dinding partisi galvanis yang dilapisi dengan rangka alumunium composite panel hollow. Rangka kaca juga terbuat dari material kaca bening dengan ketebalan $6 \mathrm{~mm}$.

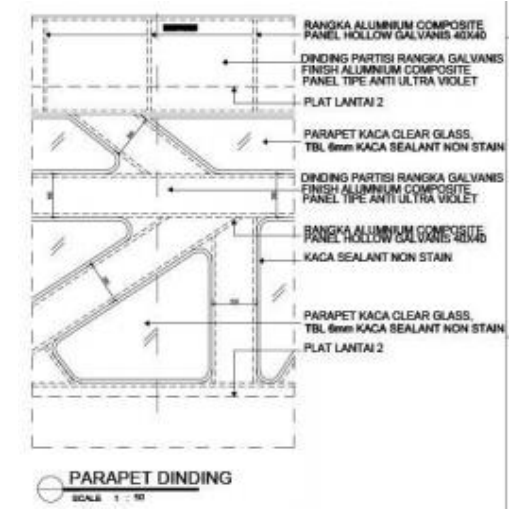

Gambar 15. Detail Parapet Dinding Sumber : Olahan Pribadi, 2021

\section{KESIMPULAN DAN SARAN Kesimpulan}

Melihat dari kondisi ekosistem terumbu karang di Indonesia saat ini cukup memprihatinkan. Masih banyak kondisi status terumbu karang yang dikategorikan buruk dan rusak yang berdampak pada penurunan keberlangsungan hidup ekosistem terumbu karang di Indonesia. Maka dengan itu perlu adanya wadah dalam menyediakan fasilitas terhadap pembudidayaan dan pelestarian terumbu karang yang menerapkan unsur terhadap kepedulian dengan alam dengan metode pendekatan biofilik arsitektur dan geometri fraktal.

Dengan adanya penerapan prinsip-prinsip metode biofilik arsitektur dan geometri fraktal 
terhadap rancangan desain fasilitas konservasi yang dapat membantu mencapai tujuan dari fungsi program. Penggunaan prinsip biofilik nature in the space, natural analogues dan nature of the space memberikan unsur penglihatan, pendengaran dan suasana pada desain bangunan. Selain itu, penggunaan fasad pada desain bangunan yang terinsipirasi dari terumbu karang juga merupakan salah satu penerapan prinsip metode geometri fraktal. Bentuk desain, struktur dan segala teknologi yang menerapkan prinsip biofilik arsitektur dan geometri fraktal membantu mencapai tujuan dari program dan fungsi bangunan dengan memberikan pengalaman untuk melampaui ekologi untuk menjaga keseimbangan ekosistem terumbu karang

\section{Saran}

Dalam melakukan pembangunan fasilitas yang berfungsi untuk menjaga ekosistem seperti bangunan konservasi dan fasilitas pembudidayaan memerlukan berbagai aspek terhadap kepentingan ekologi ekosistem laut tanpa harus merusaknya. Memperhatikan segala aspek dari segi perancangan dengan berbagai metode yang sesuai dapat membantu mencapai tujuan program.

\section{REFERENSI}

Ambari, M. (2019). MONGABAY Website diakses dari https://www.mongabay.co.id/2019/04/12/seperti-apa-ancaman-kerusakan-ekosistemlaut-besar-di-indonesia/

Authority, K. N. (2017). Rencana Pengelolaan 25 Tahun Taman Nasional Komodo . Taman Nasional Komodo: Direktorat Jenderal Perlindungan dan Konservasi Alam. Indonesia.

CASA. (2019). casaindonesia.com. Diakses dari https://www.casaindonesia.com/article/read/7/2019/1124/Apa-itu-Desain- Biophilicdan-Bagaimana-Penerapannya

Effendi, E. (2019). eckoeffendi.wordpress. Diakses dari https://eckoeffendi.wordpress.com/2009/08/01/terumbu-karang/

Hutagalung, J. (2019). Jefrihutagalung's blog diakses dari https://jefrihutagalung.wordpress.com/2009/07/06/terumbu-karang/

Johansen Mandey, J. W. (2016). Penerapan Fraktal Pada Desain Arsitektur Apartemen.

LIPI. (2018). CoreMap Terumbu Karang Indonesia. Indonesia: COREMAP.

Rahayu Effendi, H. S. (2018). Pemahaman Tentang Lingkungan Berkelanjutan.

RESTU, I. W. (2016). Ekosistem Terumbu Karang dan Statusnya.

Sutanto, A. (2021). 'Dromos Oikos' Notes On The Fifth Ecology. DKI Jakarta, Jakarta. WSJ. (2017). 10 Country Have Most Plastic in The Ocean. United States. 